\title{
nature
}

\section{Good and bad in Pakistan}

The Pakistan government is investigating whether scientists leaked nuclear technology to Iran. The affair could undermine public confidence in President Musharraf and divert attention from long-overdue reforms to science and education.

$\mathrm{D}$ id Pakistani scientists sell nuclear technology to Iran? And if they did, was the government involved? The answers to these questions cannot be known until the government completes a much-publicized investigation into the activities of its main centre for nuclear-weapons research, the Dr A. Q. Khan Research Laboratories. But it seems that the Islamabad government has already made up its mind who to blame.

The investigation has been prompted by an ongoing probe conducted by the International Atomic Energy Agency into Iran's nuclear affairs. Pakistan's government has acknowledged that Iran has named "certain individuals" as a source of technology transfer in information given to the agency. But the line from Islamabad is that any such transfers were never official policy and are more likely to have been the work of individuals motivated by "personal ambition and greed".

A number of the laboratory's civilian and military staff have been questioned, including Abdul Qadeer Khan, the country's former chief nuclear scientist, who was responsible for enriching the uranium used in Pakistan's 1998 nuclear tests.

The government's statements - coming while the investigation is being carried out - suggest that it is preparing to lay the blame on individual scientists, letting itself off the hook. This doesn't give a very favourable impression of justice in the country and is harsh on those who have a right to a fair hearing. All in all, it seems to be an abdication of responsibility by the army, which has effectively been running the lab since it was set up in 1976.

\section{Towards reform}

Alarm bells are ringing, and not just outside the country. The government's handling of the investigation is causing widespread concern inside Pakistan - particularly the fact that some of the scientists caught up in the affair have not been seen by their families since being taken for questioning. So far, the government is refusing to debate the issue in parliament, and press restrictions mean that there is very little comment and analysis in the media.

Pakistan's research community did provide a public show of support for Khan in December. He was guest of honour at a government-sponsored science conference and was praised for his achievements by President Pervez Musharraf's minister for research and higher education, Atta-ur-Rahman, who promised: "We will always stand beside you firmly."

The government's handling of the affair is unfortunate in another respect too: it is diverting attention away from what are perhaps the most far-reaching reforms to Pakistan's science for more than 20 years.

Rahman has convinced Musharraf to prise open his war-chest, and a deluge of money and new initiatives has poured out. Consider the following: the ministry of science and technology's annual budget has increased 60-fold compared with 1999; researchers have an opportunity to more than double their earnings if they publish more in peer-reviewed journals; funds have been released for many more $\mathrm{PhDs}$ to be trained at home and abroad; plans are well under way for a free digital library for all educational institutions; there is a new scheme to attract researchers from overseas to work in Pakistan; and the cabinet recently approved a plan to use science and technology to catalyse a doubling in the country's rate of growth of its gross domestic product before 2020 .

Musharraf is inspired partly by Turkey's reforming general Kemal Atatürk, who moved Turkey Westwards following the demise of the Ottoman empire in 1924. Musharraf, a diplomat's son who grew up in 1950s Turkey, sees himself as a Pakistani Kemalist, but with even more ambitious plans to reconcile Islam with modernity. He wants to write the first page of a knowledge renaissance across the Muslim world. Key to this is a plan to establish a US\$1-billion fund for research and development that will be available for the world's 57 countries that have mainly Muslim populations.

\section{Democratic change}

All of this is just a bit too giddying for Pakistan's resource-starved research community. Nine years ago, Nature sent a correspondent to survey the Pakistani science scene. The science ministry had no minister. Its total annual research spending was just \$7 million and the country produced just two PhDs per university per year. This is probably closer to the country's default research environment and many researchers are worried that Musharraf and Rahman have set standards that will be impossible to match once the general leaves office.

High-quality research needs more than money and good ideas. It needs an environment that supports democracy, the freedom to think, write and publish; an appreciation of the value of multiculturalism and diverse opinions; and the rule of law. Many Muslim countries, it has to be said, do not support such an environment. Pakistan is among the better ones and under Musharraf has taken faltering steps in the right direction.

\section{Building confidence}

What is unfortunate is that the government's current handling of the nuclear affair supports the view held by many commentators, inside and outside Pakistan, that the Musharraf regime is in effect little more than an old-style military dictatorship. The apparatus of democracy may be visible - there is a functioning parliament, local councils and a judiciary - but the spirit seems to be missing. There is no real way to challenge decisions made by the executive and no proper access to justice.

It is rare to see a research minister wielding much — if any influence over a head of state. But Rahman clearly appears to have his leader's confidence. Musharraf recently spoke of him in glowing terms: "He has taken me to a land of fantasies so many times that I now live in - and believe in - the land that he imagines. It is so real and so motivating that all I as a layman can do is to give him total support and back-up without reservation and allow him free vent and financial support for his ideas."

If Rahman has as much influence over his boss as it seems, now is the time for him to make it clear that lasting reforms need more than an injection of money, and that there should be no return to the bad old days. 